\title{
'n Kerugmatiese perspektief op bedieninge in die Nuwe Testament
}

\author{
Robert J Jones \& Andries G van Aarde ${ }^{1}$ \\ Departement Nuwe-Testamentiese Wetenskap \\ Universiteit van Pretoria
}

\begin{abstract}
A kerygmatic perspective on ministries in the New Testament

The article argues that the term "office" and its meaning, as found in the New Testament, cannot be applied without reserve to the understanding of office in the present-day church. From a Biblical and Reformed perspective, the logical place to look for clarity on this matter would be the documentation of the New Testament and the early church of the second and third centuries CE. This article investigates the origin of "office", as well as the intention of office in the New Testament and writings of the early church. A basic assumption is that the understanding of office and church cannot be separated from one another. The article illustrates that Paul's view of the church, ministries, kerygma and charismata, is of central importance for the understanding of the New Testament's intention of ministries.
\end{abstract}

\section{INLEIDING}

In die Nederduitsch Hervormde Kerk van Afrika, is daar die afgelope paar dekades besonder baie aandag gegee aan ampsbeskouing (Nederduitsch Hervormde Kerk van Afrika $1970=$ NHKA 1970; Nederduitsch Hervormde Kerk van Afrika 2001 = NHKA 2001). Hierdie debat oor ampsbeskouing is baie lewendig en dit is belangrik dat antwoorde gegee sal word rakende die teologiese en praktiese begronding van die amp. Bykans elke dissipline in die teologie kan ten opsigte hiervan 'n bydrae maak. Die volgende opmerking van Kertelge (1977:1) is daarom steeds relevant: "Die Frage nach dem kirclichen Amt im Neuen Testament, seiner Gestalt, seinem Ursprung und seiner

\footnotetext{
${ }^{1}$ Die artikel is 'n verwerking van die MA-verhandeling (2005) van ds Robert Johannes Jones, getitel "'n Kerugmatiese perspektief op bedieninge in die Nuwe Testament", voorberei onder leiding van prof dr Andries G van Aarde, emeritus professor, Department Nuwe-

Testamentiese Wetenskap, Universiteit van Pretoria.
} 


\section{'n Kerugmatiese perspektief op bedieninge in die Nuwe Testament}

geschichtlichen Entwicklung beschäftig Exegeten, systematische Theologen und Kirchenrechtler seit dem Ende des 19. Jahrhunderts bis heute mit Unvermindertem Interesse."

Vanuit 'n Bybels-Reformatoriese perspektief gesien, is dit logies om in die eerste plek die antwoord te gaan soek in die getuienis wat aan ons gebied word in die Nuwe Testament, asook in die geskrifte van die vroeë kerk. Dit is egter onmoontlik om die "amp", soos wat dit teruggevind word in die Nuwe Testament, net so op die ampsverstaan van die kerk vandag toe te pas. Daar word in hierdie artikel dus gekyk na die bedoeling van die "amp" in die Nuwe Testament en ook die inrigting daarvan in die vroeë kerk van die tweede en derde eeu.

\section{2. 'N “AMPSBESKOUING" IN DIE NUWE TESTAMENT EN DIE BEGRIP “OUDSTE”}

Omdat daar in die Nuwe Testament nie 'n voorgeskrewe bedieningstruktuur is nie (Pelser 1994:320) is dit nie moontlik om ongekwalifiseerd te praat van die "ampsbeskouing" van die Nuwe Testament nie.

Wanneer bogenoemde uitspraak rakende die bedieningstruktuur in die Nuwe Testament gemaak word, en as gevolg daarvan ook die vraag gevra word of daar iets van die hedendaagse kerklike beskouing oor die amp teruggevind word in die Nuwe Testament, is daar twee kritiese opmerkings wat eers gemaak behoort te word. Die eerste opmerking is dat die woord "amp" vreemd is wanneer oor hierdie saak gedink word in terme van die getuienis wat die Nuwe Testament daaroor bied. Wanneer verwys word na die "amp" in die Nuwe Testament, sou dit beter wees om eerder die term "bedieninge" te gebruik. Die tweede opmerking wat gemaak moet word, is dat daar gepraat behoort te word van die bedieninge in die verskillende dokumente van die Nuwe Testament. Die bedieninge in verskillende dokumente van die Nuwe Testament behoort nie in isolasie van mekaar gesien te word nie. 'n Duidelike ontwikkeling is te bespeur in die verskillende bedieningstrukture van die Nuwe Testament. Die afleiding kan dus gemaak word dat daar in die Nuwe Testament glad nie konsensus bestaan oor "amp" of "bedieninge" nie.

Die begrip "oudste" wat in die Nuwe Testament dui op 'n sekere bediening, kan teruggevoer word na die sinagogestelsel in die Israelse tradisie. Die gesag wat leierskap in antieke Israel uitgeoefen het, het voortgespruit vanuit die aansien wat 'n gesinshoof of familiehoof gehad het in die groep wat hy verteenwoordig. Dit is teen die agtergrond van hierdie gebruik wat 'n persoon die posisie van a j c is una gwgo beklee het. Louw en 
Nida (1989 I:544-545) gee die betekenis van a j c i s una g wg $0 \sim$ aan as iemand wat aan die hoof staan van die gebeure in die sinagoge of wat die leiding neem in die sinagogediens.

"Oudste" was nie 'n amp met duidelik omlynde opdragte soos wat "amp" vandag in die kerk verstaan word nie. Om die funksie van die "oudste" te verstaan of te verwoord in terme van wat vandag verstaan word onder die amp, sou 'n anakronistiese gebruik van die woord "amp" tot gevolg hê. Die oudste is nie bevestig in die "amp" of in die "posisie van oudste" nie. Die posisie is beklee op grond van die eer en aansien wat oudstes geniet het. Daarom kan ook gesê word dat oudstes bloot 'n term van eer was. Alhoewel die oudste oorwegend 'n senior ouderdom gehad het, was ouderdom op sig self nie ' $n$ beslissende faktor om te kwalifiseer as 'n oudste nie (Campbell 1994:36-38). Naas ouderdom kon wysheid ook deel uitmaak van kriteria vir iemand om te kwalifiseer as "oudste". Campbell (1994:38) beskryf dit soos volg: "This shows that eldership was not thought to be a constitutional office but something that is recognized, normally in wisdom born of experience."

Die term "oudste" het ook gefunksioneer in kollektiewe sin deurdat dit verwys het na die groep persone wat aan die hoof gestaan het van 'n betrokke groepering in die samelewing (Eks 3:16; 24:1; Num 22:7; Jos 9:11). Verder het die term "oudste" in die Qumrangemeenskap voorgekom. Uit die Dooie See Rolle kan afgelei word dat die posisie van "oudste" in hierdie gemeenskap, net soos in Israel en vroeë Judaïsme, nie 'n vasgestelde "amp" was nie, terwyl dit tog in 'n mate anders gefunksioneer het. Dit wil voorkom of die term "oudste" in hierdie gemeenskap eerder gebruik was om te verwys na 'n groep wat onder die voorsitterskap van 'n "opsighouer" byeengekom het.

In die Isrealse sowel as Grieks-Romeinse wêreld, het oudstes 'n prominente rol gespeel op grond van hulle leiersposisies. In beide hierdie wêrelde was die posisie van "oudste" verbind aan sy posisie en aansien in die huisgesin en moes die "oudste" toesien dat die huisreëls streng nagekom word. Meer as een woord bestaan om te verwys na "oudste". In hierdie verband maak Bruders (1977:83-84) die opmerking dat daar gekyk moet word na die bedoeling van 'n woord wanneer dit gebruik word om iets oor die "amp" te sê. Hy lys twee en veertig woorde wat in die Ou- en Nuwe Testament voorkom en sewe uit buite-Bybelse bronne wat gebruik kan word vir die amp. Niemand kon voorsien dat hierdie name in die jare wat volg, tegniese terme sou word waarmee "ampte" beskryf word nie.

Die agtergrond en konteks waarin woorde gebruik word, is bepalend vir die betekenis daarvan. Campbell (1994:259) wys daarop dat die ontwikkeling in die groeiende kerk daartoe gelei het dat terme soos "opsiener", "presbiter" en "diaken" titels geword het wat verwys het na spesifieke ampte met 
spesifieke funksies. Tog kan hierdie woorde volgens Campbell (1994:259) ook verwys na dieselfde mense. Oor ej i s kopo" en diakono" sê hy die volgende: "Thus, while ep i s kop o" connoted the leaders' function, dia kono", we may say, connoted their style" (Campbell 1994:259). Om hierdie argument verder te staaf gebruik hy ook die woord p r es but er 0 " en sê daaroor:

\begin{abstract}
P res buter $0 "$ ", on the other hand, connoted the character of those who thus served as overseers. To speak of overseers as elders of the community also spoke of the qualities such persons were expected to display, both before and after they were appointed. Overseers should be elders: mature, wise, able to teach and "parent" the church.
\end{abstract}

(Campbell 1994:259)

Campbell se argument kan dus saamgevat word deur te sê dat terme soos opsiener, presbiter en diaken 'n titel geword het van 'n spesifieke amp. Hiermee sê Campbell nie dat een persoon tegelykertyd in drie verskillende ampte kon dien nie. Dit moet eerder verstaan word dat elkeen van hierdie woorde ' $n$ sekere faset van die amp beklemtoon. Die afleiding kan dus gemaak word dat geen woord wat voorkom in die Nuwe Testament of in die ander dokumente in die tyd van die vroeë kerk, sondermeer verstaan kan word as verwysende na 'n ampsbegrip wat relevant moet wees in die kerk vandag nie.

Oor die begrip "oudste" kan dus samevattend gesê word: Oudstes is diegene wat leiding geneem het in godsdienstige samekomste. In sommige gevalle het vroue ook deel uitgemaak van die "oudstes". Osiek (2005:363) voer aan dat daar verskeie Nuwe-Testamentiese tekste is wat getuig dat verskeie vroue hulle huise beskikbaar gestel het vir "eredienste", waar hulle self ook die leiding geneem het.

\title{
3. DIE ONTWIKKELING VAN DIE AMP IN DIE NUWE TESTAMENT
}

Omdat elkeen van die Nuwe-Testamentiese dokumente op 'n sekere plek en in 'n sekere tyd ontstaan het, kan daar nie sprake wees van 'n ampsbeskouing in die Nuwe Testament nie. Die stelling kan wel gemaak word dat die dokumente van die Nuwe Testament elkeen afsonderlik iets sê oor "ampte" of te wel "bedieninge". Dit is egter uiters belangrik dat dit wat elke dokument hieroor bied, nie van mekaar geïsoleer moet word nie. Alhoewel elke 
dokument uniek is, is daar tog 'n ontwikkeling in die "amp" of bedieningspatrone te bespeur.

\subsection{Die beweging rondom Jesus}

Die verste wat die huidige kerkbegrip en ampsbegrip teruggevoer kan word wat die Nuwe Testament betref, is na die beweging rondom Jesus. Die beweging rondom Jesus wat verwys na die groep mense wat Jesus gevolg het en na sy prediking geluister het, is die eerste getuienis van mense wat die evangelie gehoor het.

Vir Jesus was die belangrikste dus volgens Bultmann (1955:9) nie om 'n kerk of een of ander geloofsgemeenskap te stig nie, maar om die boodskap by die mense tuis te bring dat hulle hulle gehoorsaam aan God moet onderwerp. Vir Jesus het dit nie gegaan oor 'n struktuur waarbinne mense hulleself moet organiseer tot 'n kerk nie. Die kern van die saak waarom dit vir Jesus gegaan het, en wat ook die kernboodskap van sy prediking was, is dat mense hulle moet bekeer, want die koninkryk van God het naby gekom. Jesus het in die indikatief van sy prediking duidelik uitgespel wat God van mense verwag. Op imperatiewe wyse het Jesus in sy prediking die mens opgeroep om in gehoorsaamheid aan die wil van God te gaan leef.

Met verwysing na Matteus 16:17-19 merk Trilling (1978:58) ook op dat dit vir Jesus nie daarom gegaan het om 'n kerk te stig nie. Op grond van hierdie teks maak hy verder die opmerking dat dit eerder daaroor gaan dat Jesus iets van die koninkryk van God sigbaar kom maak het en dat die besondere verhouding tussen Jesus en die kerk nie lê in die feit dat dit Jesus se doel was om 'n kerk te stig nie. Die besondere verhouding tussen Jesus en sy kerk lê eerder in die verhouding tussen die boodskap wat Hy deur sy prediking gebring het en die kerugma van die kerk. "Oder anders: ob man unter der Hypothese, daß sich keine historisch-exegetisch traghäftige Begründung dafür fände daß Jesus eine Kirche 'gedacht' - 'gewollt' - oder gar 'Gegründe' habe, dennoch vom einem Zusammenhang, ja vieliecht sogar von einer 'notwendigen' Bezogenheit, sprechen dürfe" (Trilling 1978:59).

Om werklik kerk te wees gaan dit, volgens Schweitzer (1959:18) weer, nie oor strukture wat in plek moet wees nie, maar mense wat in die regte verhouding met God moet lewe. Hy noem dit 'n ommekeer na God. Met die beste strukture en gemeentelike orde is hierdie ommekeer na God nog nie voltrek nie. Om by die regte bedoeling van die bedieninge in die Nuwe Testament uit te kom, beteken dus 'n voortdurende omdraai en terugkeer na God. Die regte bedoeling agter die bedieninge in die Nuwe Testament, maar ook in die kerk, verseker nie 'n ommekeer na God nie. Dit is eerder die 


\section{'n Kerugmatiese perspektief op bedieninge in die Nuwe Testament}

voortdurende ommekeer na God wat die regte bedoeling agter die bedieninge in die kerk, in die Nuwe Testament en ook vandag, verseker.

Dit is nodig om te verstaan dat die beweging rondom Jesus 'n beweging was wat bestaan het tussen en saam met ander bewegings van die tyd. Die ander bewegings of groeperinge wat bestaan het, het elkeen hulle eie aard en doel gehad.

Waar pas die Jesus-beweging in tussen al die ander groeperinge van die tyd? Dunn (1981:104) voer aan dat die verhouding tussen Jesus en sy dissipels die beste beskryf word deur dit te vergelyk met die verhouding tussen 'n rabbi en sy leerlinge. Markus gebruik twee verskillende aanspreekvorme vir Jesus, naamlik r abbiven didas kal o". Al twee die aanspreekvorme wat hy gebruik, dui daarop dat Jesus 'n leermeester was. Met bogenoemde aanspreekvorme in gedagte, is die vraag nou of daar gepraat kan word van 'n gemeenskap rondom Jesus en of daar in Jesus en sy dissipels rondom Hom iets weerspieël word van die kerklike gemeenskap van vandag?

Wanneer verwys word na die volgelinge van Jesus moet daar eerder gepraat word van 'n beweging as 'n gemeenskap. Hierdie beweging rondom Jesus is gekenmerk deur openheid. Daar is geen toelatingsvereistes gestel vir iemand om hiervan deel te word nie. Om deel van hierdie gemeenskap te word, was daar een saak wat bepalend was en dit was om die wil van God te doen.

Alhoewel Jesus en sy dissipels nie "kerklike rituele" beoefen het en geen rituele ook as toelatingsvereistes gestel is om deel van die beweging rondom Jesus te word nie, staan die saak van gehoorsaamheid en die doen van die wil van God tog baie pertinent uit. Dit is ook nodig om te meld dat Jesus nie die rituele wat wel beoefen is (soos byvoorbeeld die was van hande voor 'n maaltyd), van die tafel afvee nie (Mark 7:1-20). Jesus lê wel klem daarop dat die belangrikste doel in hierdie rituele moet wees dat die eer van God daardeur gedien word. Loader (2001:39-40) verwoord dit soos volg: "With Jesus it was doubtless a matter of degree, as we have seen it. He was not advocating neglect of the food laws enshrined in Scripture, but making the point that they were not nearly as important as impurity within a person. The impurity that matters is in people's attitude and behaviour."

Jesus het geen kerk gestig nie, ook nie rituele daargestel as vereistes om deel van hierdie beweging rondom Hom te word nie. Die rede hiervoor is omdat daar geen heil daarin bestaan om in 'n religieuse gemeenskap in te gaan of deel daarvan te word nie. Heil kom van God alleen. Die heil van die mens lê dus nie in die strukture van die kerk nie, maar in 'n positiewe antwoord op Jesus se oproep tot dissipelskap (Matt 16:24-28). Dit sal eerder 
korrek wees om te sê dat Jesus die koninkryk verkondig het en dat Hy mense opgeroep het om hulle te bekeer en die wil van God te doen, as wat dit sy bedoeling was dat die heil van die mens verwerklik word in rituele of in een of ander struktuur.

\subsection{Die dissipelbeeld in Matteus en Markus}

Dikwels word die dissipelbeeld in die Sinoptiese Evangelies voorgehou as ' $n$ model waarop die ampsbegrip van hierdie twee Evangelies gebou is, en daarom die model waarop die ampsbegrip van die kerk gebou moet word. Met hierdie stelling is daar tekortkominge wat tot gevolg het dat dit nie moontlik is om hierdie werkwyse te volg nie.

Wanneer na 'n ampsbegrip gesoek word in die dissipelbeeld, is dit beter om 'n stap terug te neem en die antwoord te gaan soek in die eise wat Jesus stel aan dissipelskap, soos in Matteus 16:24-28 en Markus 8:34-38. In die eise wat Jesus stel, het ons te doen met dit wat God van mense vra. In die eise wat God stel, lê die ware karakter van dissipelskap en nie in die optrede van die dissipels in Matteus en Markus nie. Dit is die woorde van Jesus wat 'n mens die naaste bring aan dit wat God van jou vra, en nie die manier waarop die dissipels geleef het nie.

\section{DIE BEDIENINGE BY PAULUS}

Ten einde 'n Pauliniese "ampsbegrip" te formuleer, is dit van belang om eers die kerkbegrip soos dit voorkom in die Pauliniese briewe te verdiskonteer. Hierby sluit Pelser (1990:8) ook aan wanneer hy sê: "Dat Paulus se verstaan van die wese en funksie van die bedieninge van sentrale betekenis is vir enige ondersoek van bedieninge in die Nuwe Testament, het geen bewysvoering nodig nie." Verder kan ook gesê word dat Paulus se eie verstaan van die Christusgebeure, sy eie unieke roepingsbewussyn as apostel, sy verstaan van wat die kerk is en ook sy verstaan van die Gees se rol in die kerk, die grondslag vorm vir sy verstaan van die bediening in die kerk.

\subsection{Kerkbegrip}

Paulus se kerkbegrip sentreer rondom twee gedagtes (Pelser 1995:647). Die eerste gedagte is dat die kerk ' $n$ saamwees is van mense wat onderling aan mekaar verbonde is. Hierdie gedagte begrond Paulus in mense se verbondenheid aan Christus en kan saamgevat word in die "in-Christus" gedagte wat baie prominent is in die teologie van Paulus. Hierdie gedagte verwoord Paulus met die ej C r is t w formule wat eg-Paulinies is. Volgens Pelser \& Van Aarde (2004a:79) het hierdie formule nie orals waar Paulus dit 


\section{'n Kerugmatiese perspektief op bedieninge in die Nuwe Testament}

gebruik, dieselfde betekenis nie maar is een van die betekenisse daarvan dat die gelowige op een of ander besondere manier aan Christus verbind is. Hiermee sê Paulus dat almal wat "in-Christus" is, deel aan die heerlikheid van sy opstanding en die lewe daarna. Dit is hierdie gemeenskaplikheid van wat hulle deel, wat hulle aan mekaar verbind dat hulle saam verbonde kan wees aan Christus.

Volgens Paulus se verstaan van die kerk, kan die kerk net bestaan as die Heilige Gees die saam-wees van mense "in Christus" in stand hou en dit doen deur aan verskillende mense verskillende gawes te gee. Die kerk kan dan volgens Paulus ook nie bestaan sonder die gawes van die Gees nie, en daarom ook nie die "ampte" in die kerk nie. Die hele saak rondom gawes en ampte word later meer breedvoerig bespreek. Die tweede gedagte in die kerkbegrip van Paulus, het te make met die Godsvolk as deel van die nageslag van Abraham. Hy noem die Godsvolk die nageslag van Abraham, omdat dit deur hierdie lyn is wat die kontinuïteit van God se verlossingshandeling en heilshandeling loop.

In die Pauliniese gemeentes was daar 'n groep wat Judaïserend opgetree het (kyk Watson 2003:77-100; veral bl 97). Hulle het gelowiges so beïnvloed dat hulle moet glo niemand kan deel van die Godsvolk wees as hulle nie van Israelse afkoms is en die Israelse gebruike en voorskrifte handhaaf nie. Paulus maak 'n groot saak rakende die nageslag van Abraham uit. Hy gebruik vir Abraham as voorbeeld, klaarblyklik omdat Abraham as aartsvader en geloofsheld groot aansien gehad het onder die Israeliete. Paulus stel dit dan vir hulle baie duidelik dat jy deel word van die geestelike nageslag van Abraham, wanneer jy in die nakomeling van Abraham, Jesus Christus, glo en met Hom verenig is deur die doop. Dit is slegs wanneer Paulus oor die kerk praat in teenstelling tot die ongelowige Israel, dat hy daarna verwys as "Godsvolk". Met die gebruik van hierdie terme gaan dit vir Paulus oor die kerk wat bestaan uit Israeliete en nie-Israeliete.

Alhoewel die kerk as liggaam van Christus sekerlik die bekendste beeld van die kerk in die Nuwe Testament is, is dit baie belangrik om daarteen te waak dat dit nie geïsoleer word van ander metafore wat in die Nuwe Testament gebruik word om iets van die kerk te sê nie. Wanneer hierdie metafoor gebruik word om iets van die kerk te verwoord, moet 'n mens jouself baie goed daarvan vergewis of hierdie metafoor wil sê die kerk is die liggaam van Christus, en of Paulus daarmee die kerk vergelyk met 'n organisme, naamlik die menslike liggaam. Met hierdie voorstelling wil Paulus nie iets van die aard of wese van die kerk sê nie, maar gebruik hy dit alleen in die paranetiese sin van die woord. 
Die kerk as liggaam van Christus vorm volgens Käsemann (1933:170171) nie die sentrum van die Pauliniese gedagte van kerk-wees nie. Dit dien slegs as 'n hulplyn; om iets te sê van die verskeidenheid en eenheid van die kerk omdat die organismegedagte van kerk-wees nie rym met die Pauliniese antropologie, sakramentsteologie en Christologie nie. Käsemann (1933:170171) verwys soos volg hierna: "Nun ergibt sich, da $\beta$ I Kor 12:14-21, von fast der gesamten theologischen Interpretation als Zentrum der paulinischen Vorstellung vom Christusleibe angesehen, in Wirklichkeit nur eine Hilfsline ist."

\subsection{Charisma of amp}

Dat Paulus die bedieninge in sy gemeente as charismaties geklassifiseer het, is baie duidelik. Daarom is dit belangrik om te verstaan dat Paulus nie charisma en "amp" teenoor mekaar gestel het nie. Die vraag wat egter beantwoord moet word, is in watter mate Paulus die terme charisma en "amp" met mekaar verbind het, en watter gesag hy aan elkeen toegeken het. Die ander vraag wat beantwoord moet word, is wat Paulus bedoel wanneer hy praat van spesifieke bedieninge in die gemeente.

Wanneer Paulus van hierdie spesifieke bedieninge praat, sluit dit almal in die gemeente in. Elke Christen in die gemeente het bepaalde charismata ontvang. In hierdie bedieninge in die gemeente, waar almal deel het aan die bediening op grond van die charismata wat hulle van God ontvang het deur die Gees, is hulle 'n heilige priesterdom wat deur die doop met die Gees verenig is.

Interessant dat, alhoewel Paulus nie pertinent sekere bedieninge of charismata uitsonder bo ander nie, hy tog in 1 Korintiërs 12:28 drie bedieninge in 'n sekere rangorde rangskik, naamlik apostel, profeet en leraar. Oor die gawes wat Paulus opnoem, sê Dunn (1988:735): "And clearly his list in I Cor 12:8-10 was drawn up with a view to the particular situation in Corinth, not as some kind of universally applicable, far less exhaustive, list of 'charism'."

Hieruit kan dus die afleiding gemaak word dat wanneer Paulus die klomp gawes noem nadat hy van die drie belangrike bedieninge gepraat het, hy nie met die gawes 'n spesifieke rangorde bedoel nie. Hy het wel sekere maatreëls getref om orde in die gemeente te handhaaf. Volgens Morris (1985:174-175) moet hierdie lys van bedieninge wat Paulus hier pertinent uitsonder, gelees word saam met 1 Korinthiërs 12:24 waar hy verwys na die liggaam van Christus. Ook hier moet die liggaambeeld verstaan word in die paranetiese sin van die woord en nie as 'n fisiese verbintenis tussen Christus en sy liggaam, die kerk, nie, soos wat dit ook hierbo beredeneer is. Hieroor sê 


\section{'n Kerugmatiese perspektief op bedieninge in die Nuwe Testament}

Morris (1985:174): "People do not choose to be apostles, prophets, and the rest, but God sets them in the church. First of all ... second ... third picks out three specially significant gifts. We cannot press the order throughout the list, though clearly none of the rest is to be ranked with the first three." Hahn (1979:436) maak die stelling dat die drie bedieninge wat in 1 Korintiërs 12:28 ter sprake is, vir Paulus die belangrikste was en dat dit as 't ware as "ampte" beskou kan word: "Wovon Paulus dagegen nicht spricht, ist die heute vielbeschworene "Gleicheit" der Charismen."

Dit sal die moeite loon om te kyk na 'n opmerking wat Karl Barth (1968:445) maak oor dit wat hy verstaan het onder Paulus se bedoeling met "gawes". Alle gawes kom van God af. Wanneer God hierdie gawes aan mense gee, versteur God as 't ware die menslike gang van die lewe. Uit dit wat Barth 'n "versteuring" noem, kan verstaan word dat wanneer God hierdie gawe aan jou gee en jy dit ontdek, dit onmiddellik 'n verantwoordelikheid op jou plaas om hierdie gawe te gebruik in diens van God, in diens van die gemeente en ook tot voordeel en uitbou van God se koninkryk hier op aarde. Hierdie stelling laat die gedagtegang ook onwillekeurig gaan na die gelykenis wat Jesus in Matteus 25:14-30 vertel het van die muntstukke.

Paulus meen dat 'n mens hierdie verantwoordelikheid besef en die gawes van God uitleef wanneer mense hulleself diensbaar maak in die kerk. $\mathrm{Na}$ my mening is die uitoefening van dienswerk dus 'n ketting met verskeie skakels. Die eerste skakel is die charismata wat van God ontvang is. Die tweede skakel is dat die roepstem van God gehoor word in hierdie charismata wat God gee. Die derde skakel is die antwoord daarop wat gestalte vind in die praktiese uitvoering van hierdie dienswerk.

Twee sake wat baie belangrik is wanneer die debat oor "ampte" in die Pauliniese gemeentes gevoer word, veral met verwysing na 1 Korintiërs 12:28 en Romeine 12:6-8, is eerstens dat ons in die teks van 1 Korintiërs te doen het met drie spesifieke bedieninge, maar ook met verskeie dienste, oftewel gawes wat genoem word. In die gedagtegang van Paulus is hierdie gawes niks anders as gawes van die Gees nie, met ander woorde die charismata waarin hy die bedieninge in die gemeente begrond. Tweedens is dit van uiterste belang om die bedieninge wat in 1 Korintiërs genoem word en dié wat in Romeine genoem word, elkeen teen hulle eie unieke agtergrond en "gemeentelike omstandighede" te sien.

Daar bestaan dus geen twyfel daaroor dat Paulus die charisma sien as dit waarin enige diens in die kerk begrond moet wees nie. Dienswerk word dus begrond in die ontferming van God oor mense en bepaalde gawes aan mense gee ten einde God se orde in die kerk te handhaaf en ook daardeur die kerk te lei en te regeer. Die wesenlike van dienslewering is dat 'n 
onbekwame mens deur God tot hierdie diens geroep word. Die geroepene ontvang dan genade van God om sy of haar roeping uit te voer. Gelowiges besef ook dat die krag om hulle roeping uit te voer, nie van die mens self kom nie, maar dat ook dit deel is van die wonder van God se genade.

Myns insiens kan aanvaar dat al die bedieninge waarna Paulus verwys het, op een of ander wyse dui op die uitoefening van dienswerk in die kerk, maar ook op die regering van die kerk. Die presiese vorm wat dit aangeneem het, is nie vir ons duidelik nie.

\subsection{Diakonia, charisma en amp}

Daar kan verder lig gewerp word op die verhouding tussen charisma en amp by Paulus, wanneer duidelikheid verkry word oor sy verstaan van diakonia, en hoe hy hierdie begrip inkleur. 'n Antwoord op hierdie vraag sal help om Paulus se "ampsbegrip" beter te verstaan en ook om te weet of daar in die Pauliniese gemeentes werklik iets soos ampte bestaan het al dan nie.

Volgens Schelke (1969:228-229) is die begrip diakonia in die Nuwe Testament die allesomvattende en wesenlike begrip vir die amp. Hierdie amp het volgens hom die opdrag om te bestuur asook die bevoegdheid om te rig en te straf. Paulus se gebruik van hierdie term sou ook dui op sy verstaan dat charisma as 'n oorkoepelende term gebruik word vir diakonia in sy gemeentes. Al sou diakonia ophou om te bestaan, beteken dit nie dat charisma daarmee saam verdwyn nie. Die charismata in die kerk is dus nie van die diakonia afhanklik vir voortbestaan nie.

Oor Paulus se verstaan en gebruik van die term diakonia sê Hahn (1979:427) dat die begrip diakonia in die Nuwe Testament nêrens iets te make het met die amp nie. Dat daar wel 'n sterk band bestaan tussen charisma en diakonia is nie te betwyfel nie. Dit verwoord Hahn (1979:427) soos volg:

Es kann darüber hinaus eine speziellen "Dienst" bezeichnen so da $\beta$ mit diakoni a eine Gnadengabe neben anderen charakterisiert wird. Scheidet diakonia als übergeordneter Begriff weitgehend aus, dann bleibt zu überlegen, ob nicht der cavis ma-Begriff hierfür sehr viel besser geeignet ist. Zwar kommt er in diesem Sinn nur relativ selten im Neuen Testament vor. Aber der Inention des Paulus nach nimt er tatsächlich diese Stelle ein.

Wat baie belangrik is om op te let oor Paulus se gebruik van diakonos of diakonia, is dat hy nie daarmee bedoel die versorging van armes, soos wat ons in die boek Handelinge aantref of die moderne betekenis wat ons in die kerk vandag daaraan gee nie. Met hierdie terme bedoel hy eenvoudig 


\section{'n Kerugmatiese perspektief op bedieninge in die Nuwe Testament}

dienslewering in die kerk. Wat hierdie dienswerk betref, is dit belangrik om te beklemtoon dat dit dienswerk is wat te make het met die evangelie.

Die begrip diakonos is gebruik deur die Grieke in kontekste binne en buite dié van godsdiens en kerk. Dit het gedui op mense wat algemene welsynswerk gedoen het, maar ook is dit gebruik om iets te sê van tempeldiens wat verrig is. In die Nuwe Testament word die titel diakonos verhoog tot ' $n$ absolute titel van diens. Dit het gebeur as gevolg van dit wat Jesus geleer het. Jesus het met sy onderrig en prediking 'n boodskap verkondig, wat ook die boodskap van die evangelie is. Met hierdie boodskap het Hy ingegaan teen die wêreld se idees van dienslewering. Die feit dat die wêreld neergesien het op iemand wat diens lewer, draai Jesus om wanneer Hy sê dat om groot te wees lê in die vermoë of geleentheid om te kan dien (Mark 10:43). By hierdie gedagte sluit Paulus ook aan wanneer hy sê dat die hart van diakonos lê in dienslewering aan ander.

Die diakonoi sou die armes versorg, maar ook na die siekes omsien en dié wat in die tronk is, besoek. Dit is dus duidelik dat die pligte van die diakonos meer behels het as net die materiële versorging van die armes. Wanneer Paulus praat van diakonia as die "dienste van die Gees", is dit volgens Kertelge (1977:3) 'n manier waarop Paulus iets van die apostelamp wil beskryf. Die term diakonos dui dus op dienslewering in die kerk wat die versorging van die armes insluit, en nog baie ander pligte ook het.

\subsection{Bevinding oor bedieninge by Paulus}

Hierbo is verwys na verskeie tekste uit die briewe van Paulus om daarmee lig te werp op die vraag wat nou ter sprake kom, naamlik: "Was daar in die Pauliniese gemeentes alreeds 'n inrigting van sekere ampte, of het die Pauliniese gemeentes slegs gefunksioneer op die unieke charismata wat van mekaar verskil het, wat God deur sy Gees aan elkeen van die lidmate van hierdie gemeentes gegee het?"

Dit is duidelik dat daar uit die Pauliniese gemeentes bedieninge na vore getree het wat op 'n gereelde grondslag beoefen is. Sonder sommige van hierdie bedieninge sou die gemeentes in 'n mate nog oor die weg kon kom. Die onmisbare bediening, waarsonder die gemeente glad nie meer sou kon bestaan nie, is die verkondiging van die Woord. As gevolg van die uitbly van die paroesie kan met stelligheid gesê word dat die bedieninge op 'n gereelde basis beoefen was. Dunn (1981:111) stel dat charismata by Paulus 'n spesifieke uitdrukking van genade of spesifieke manifestasie van die Gees beteken. 'n Christelike gemeenskap bestaan slegs in 'n lewende interaksie van charismatiese bedieninge. Hierdie bedieninge wat plaasvind, is 'n 
manifestasie van die genade van God. Dit is ook in hierdie manifestasie van God se genade wat die lewende interaksie tussen gelowiges plaasvind.

Omdat die wederkoms nie so vinnig plaasgevind het as wat die mense van die tyd verwag het nie, sou die voortbestaan van die kerk ernstig bedreig word, indien die manifestasie van hierdie bedieninge en daarom ook charismata, slegs sporadies plaasgevind het. Daarom was voortdurende manifestasie van die bedieninge by Paulus van uiterste belang.

By Paulus is daar nie ampte ter sprake soos in die latere sin van die woord, byvoorbeeld by die Pastorale Briewe en eerste- en tweede-eeuse kerk nie. Almal wat bedieninge in die Pauliniese gemeentes beoefen het, is nie in 'n amp georden soos wat die geval was in die era ná Paulus nie. Daarom kan Schweitzer (1987:47) gelyk gegee word wanneer hy stel dat daar, wat die Pauliniese gemeentes betref, nie gepraat kan word van "ordening" in 'n amp nie, maar slegs van 'n "erkenning" van bedieninge.

$\mathrm{Na}$ aanleiding van wat hierbo gesê is, is ek van mening dat Paulus se beskouing oor die bedieninge vanuit 'n kerugmatiese perspektief belig kan word. Dit word gedoen deur sy verstaan van die bedieninge in die Nuwe Testament te bou op vier bene, wat ons ook kan noem "kerugmatiese waarhede". Hierdie "kerugmatiese" waarhede behels Paulus se beskouing van die kerk, charisma, bediening en kerugma. Omdat die deutero-Pauliniese briewe en ook die Pastorale Briewe sterk onder die invloed van die Pauliniese teologie was, is dit nodig om die invloed van hierdie vier "kerugmatiese waarhede" op die deutero-Pauliniese en Pastorale Briewe ook te bespreek. Met die verduideliking van die invloed van die Pauliniese teologie, en daarom ook die vier "kerugmatiese waarhede", op die deutero-Pauliniese- en Pastorale Briewe, en ook die invloed daarvan op die ampsbeskouing van die tweede- en derde-eeuse kerk, sal die bedieninge in die Nuwe Testament in 'n kerugmatiese perspektief gestel word.

\subsection{Die deutero-Pauliniese briewe}

In die bespreking van die deutero-Pauliniese briewe, val die fokus op Kolossense en Efesiërs. Die invloed van die Pauliniese teologie op die deutero-Pauliniese briewe word baie duidelik geïllustreer met verwysing na drie voorbeelde waarop Pelser \& Van Aarde (2004b:41-42) in die Kolossensehimne en Kolossense 1:15-20 wys.

Eerstens kan verwys word na die toevoeging "deur die bloed van die kruis". Die outeur wend daarmee 'n poging aan om die gedagte oor die versoening in die lied te voorsien van die grondliggende element van die Pauliniese versoeningsgedagte, naamlik die kruisdood van Jesus Christus. In die tweede plek figureer Paulus se metafoor van die kerk as liggaam van 


\section{'n Kerugmatiese perspektief op bedieninge in die Nuwe Testament}

Christus prominent. Met die byvoeging van "die kerk" in hierdie himne, wil die outeur, teen die agtergrond van Paulus se denke oor die kerk as liggaam van Christus, hierdie himne korrigeer en stel dat Jesus die Hoof van die kosmos en van die kerk is. So is Christus ook Hoof oor al die bose magte. Derdens kan die toevoeging "sodat Hy die eerste plek in die heelal inneem" waarskynlik aan dieselfde oorweging van die outeur toegeskryf word.

Met die invloed wat die Pauliniese teologie op die deutero-Pauliniese teologie het, in gedagte, word twee temas nou meer spesifiek hanteer ten einde vas te stel hoe die bedieninge gefunksioneer het in die deuteroPauliniese briewe.

\subsection{1 'n Geïnstitusionaliseerde kerkbegrip}

Wanneer Paulus oor die kerk praat, doen hy dit baie spesifiek deur te praat van "die kerk". Kolossense en Efesiërs praat baie meer algemeen van die kerk deur slegs daarna te verwys as "kerk". Die liggaammetafoor in Kolossense en Efesiërs het hier 'n doksologiese doel, anders as by Paulus waar dit 'n paranetiese doel het. Schnackenburg (1961:76) tref 'n vergelyking tussen die gebruik van die liggaam van Christus-metafoor in die Pauliniese en deutero-Pauliniese korpus deur te sê dat hierdie metafoor in Kolossense en Efesiërs 'n nuwe neiging toon en opnuut weer 'n oplewing beleef.

Die beeld wat van die kerk gegee word in Kolossense en Efesiërs is volgens Pelser (1995:659) 'n idealistiese beeld. Met die voorstelling van die kerk as ideaal, moet daar sterk daarteen gewaak word dat die werking van die Gees in die proses nie beperk word tot dit wat die mens van die kerk wil maak nie. In Kolossense en Efesiërs wil dit lyk of die kerk as entiteit reeds begin het om 'n institusionele karakter te toon. Dit kan gestaaf word deur daarna te verwys dat Paulus homself beskryf het as 'n dienaar van God of dienaar van die nuwe verbond maar die skrywer van die Kolossense brief beskryf homself as dienaar van die kerk (Brown 1984:53).

Die feit dat die kerk in Kolossense 'n geïnstitusionaliseerde karakter toon, word gestaaf deur drie gedagtes in Kolossense. Eerstens word dit weerspieël in die manier waaroor daar oor die doop gepraat word. Dit lyk of die doop reeds funksioneer as 'n formele toelatingsakte tot lidmaatskap van die kerk. Tweedens dra die gedagte van die huistafel ook by tot die institusionalisering van die kerk. Oor die huistafel sê Pelser \& Van Aarde (2004b:65): "Gedagtes oor die huistafel, vind ons slegs in dié dokumente van die vroeë kerk wat 'n institusionaliserende tendens vertoon, en gevolglik nie in die onomstrede Paulusbriewe nie." Die derde gedagte is die bestryding van dwaalleer wat baie klem kry. Hierdie groepie mense wat hulleself moet inrig en in vrede met mekaar saamleef tot en met die tyd wat die wederkoms 
plaasvind, beleef nou 'n bedreiging van buite. Die dwaalleer waarvan gepraat word, bedreig die eenheid van die kerk. Daarom moet hierdie groepie mense wat nou 'n (geïnstitusionaliseerde) eenheid vorm, saam stry teen hierdie dwaalleer wat die kerk, onder andere ook as instituut, bedreig.

Wat die Efesiërbrief betref, kan met stelligheid gesê word dat die kerk die tema is van hierdie brief. Die kerk word meer beskryf in die universele sin van die woord en nie meer as die plaaslike gemeente nie. Met gebruikmaking van die terme wat Hainz (1972:229-255) gebruik, kan daar gesê word dat hier 'n verskuiwing plaasvind vanaf die Einzelgemeinde na die Gesamtkirche. In die Efesiërbrief word lidmate opgeroep om hulle gereed te maak vir 'n uitgestrekte bestaanswyse in hierdie wêreld. Hulle word pertinent opgeroep om geestelik te groei onder leiding van die Heilige Gees. Die lesers word duidelik opgeroep om hulle lewens deur die Gees te laat beheers. Hierdie nabye verwagting van die wederkoms bestaan nie meer in Efesiërs nie, en daarom toon Efesiërs 'n sterk institusionele karakter van die kerk. Daarom word die kerk ook nie meer verstaan as 'n historiese grootheid nie, maar eerder as 'n tydlose grootheid. In die Kolossensebrief is daar bykans glad nie sprake van die Gees nie.

In Efesiërs word die verhouding tussen Christus en die mens beskryf teen die agtergrond van die verhouding tussen Christus en die kerk. Op mense word 'n appèl geplaas van hoe hulle hulle lewe moet inrig. Die indikatief van Jesus se lewe, is dus die imperatief vir die lewe van die kerk. Die hele gedagte rondom die institusionele sy van die kerk word verder gevoer in Efesiërs wanneer die stelling gemaak word dat die kerk gebou is op die fondamente van die apostels en profete. Hierdie stelling is die bevestiging dat die kerk nie net as hemelse grootheid gesien word nie, maar dat dit ook neerslag vind in empiriese aardse gemeentes. Die kerk waarvan in Efesiërs sprake is en aan wie die apostels en profete as gawes gegee is, dui nie meer op plaaslike gemeentes soos wat daar by Paulus sprake is van die kerk nie, maar eerder op 'n meer universele verstaan van kerkwees (Pelser 1990:11).

Uit die kerkbegrip van Efesiërs is dit baie duidelik dat Christologie en ekklesiologie in mekaar verweef is. Dit is af te lei uit die feit dat wat oor die kerk gesê word, in samehang met Christus gesê word (Ef 2:20; 5:21-33). Op grond van die feit dat die klem baie sterk geplaas word op die heilsbemiddelende faktor van die kerk, kan ook gesê word dat die Christologie en soteriologie in mekaar verweef is. Die kerk speel hiervolgens 'n beslissende rol in die verlossing van die mens.

Oor die kerk van Efesiërs kan dus met groot stelligheid gesê word dat die kerk 'n baie duidelike institusionele karakter toon. Hierdie institusionele karakter van die kerk word ook gevind in die beskrywing van die huistafel in Efesiërs. Dit word veral sigbaar waar die verhouding tussen man en vrou 


\section{'n Kerugmatiese perspektief op bedieninge in die Nuwe Testament}

beskryf word op grond van Jesus se verhouding met sy kerk. Alhoewel die huistafel in Kolossense ook beskryf word, word dit in Efesiërs verder uitgebrei.

\subsection{2 'n Geïnstitusionaliseerde ampsbegrip}

Alhoewel Paulus die term "dienaar" deurlopend gebruik het in sy briewe, en ook in verskillende verbande, het hy nie daardeur 'n kerklike amp probeer aandui nie. Die skrywer van die deutero-Pauliniese briewe voer egter hierdie bedieninge 'n stappie verder. Hy sê pertinent dat hy 'n dienaar van die kerk geword het deur 'n opdrag wat hy van God ontvang het. Die werk wat in diens van die evangelie gedoen is, is al meer en meer gesien as werk in diens van die kerk. Hierdie verskynsel is baie duidelik 'n na-Pauliniese ontwikkeling. In die deutero-Pauliniese briewe het iets van 'n ontwikkeling in die beskouing van die bedieninge begin deurskemer na aanleiding van die institusionele karakter wat die kerk begin toon het. Die stelling kan dus gemaak word dat die "ampsbegrip" van die kerk ontwikkel het in die spoor van die kerkbegrip se ontwikkeling. Oor hierdie ontwikkeling van die konsep van bediening in Efesiërs, maak Roloff (1978:523) die volgende opmerking: "Auf breiter Front vollzog sich in nachpaulinischer Zeit die Verschmelzung der paulinischen Episkopenverfassung mit der palästinischen Ältesverfassung ..." Hiermee bedoel Roloff dat die bedieninge, soos gevind by Paulus, begrond word in bepaalde charisma wat God deur die Gees aan mense gee. Met die institusionalisering van die kerk, wil dit lyk of die klem ietwat van die charisma af wegbeweeg het en geplaas is op die amp self.

Nadat alles gesê is oor die ampsbeskouing van Efesiërs, moet die opmerking ook gemaak word, dat al het die skrywer van die Efesiërbrief gedink in terme van 'n meer geïnstitusionaliseerde kerk, dit vir hom óók daaroor gegaan het dat die kerk nie sou kon bestaan sonder die gawes wat God gee nie. Ampte is dus 'n vergestalting van die genade wat God teenoor die kerk toon, wat terselfdertyd gegrond is in die genadegawes wat God aan mense gee.

\subsection{Die Pastorale Briewe}

Net soos in die Efesiërbrief, vorm die kerk die sentrale tema van die Pastorale Briewe. Die metafoor waarmee die kerk in hierdie briewe beskryf word, is dié van 'n huisgesin. In die Pastorale Briewe is 'n eie orde van die kerk ook alreeds te bespeur.

Die wegbeweeg vanaf die liggaammetafoor (wat Paulus gebruik en wat in die deutero-Pauliniese briewe nog baie sterk figureer) na die metafoor van die huisgesin, wil dit laat blyk of die kerk op 'n baie meer konkrete manier sigbaar word in die wêreld. Hierdie bewering word gemaak omdat die metafoor van die kerk as huisgesin meer konkreet en verstaanbaar is as die 
metafoor van die kerk as liggaam van Christus. Hierdie beweging na 'n meer konkrete beskrywing van die kerk, het ook 'n uitwerking op die ampsbeskouing van die Pastorale Briewe. Dit word onmiddellik sigbaar wanneer die ampte in die Pastorale Briewe anders beskryf en uiteengesit word as die bedieninge by Paulus, en in 'n mate ook by die deutero-Pauliniese briewe, met verwysing na die gebruik en interpretasie van die charismata.

Pelser \& Van Aarde (2004b:44) voer aan dat daar in die Pastorale Briewe nêrens duidelik omlynde pligte gegee word van wat die werk van elke amp behels nie. Dit word duidelik uitgespel aan watter persoonseienskappe die ampsdraers moet voldoen. Die etiese en morele sy van die ampsdraer word beskryf, terwyl die praktiese sy van die ampswerk agterweë gelaat word. Dit is baie opmerklik dat die bedieninge in die Pastorale Briewe baie duideliker uiteengesit is as by Paulus. Die titels wat gegee word aan verskeie ampsdraers, soos byvoorbeeld opsieners/ouderlinge en diakens, dui daarop dat die konsep "amp" 'n ontwikkeling deurloop het en ook goed gevestig is teen hierdie tyd. Die gebruik van die term episkopos in 1 Timoteus 3:1 dui die funksie van 'n sekere bediening aan. Die persoon neem dus 'n sekere posisie in die gemeente in. Alhoewel die konsep van verskillende ampte hier al reeds goed gevestig is, is hier nog nie sprake van die monargiese biskop wat die gesagdraer in die kerk was, soos wat dit teen die tweede eeu na vore getree het nie. Die episkopos is hier nog besig om te ontwikkel tot die amp van biskop, soos wat dit later gestalte gevind het. Tog vind 'n mens hier wel 'n konsentrasie van gesag, en die funksie van 'n reeds gevestigde amp van episkopos (Brox 1969:149).

Dit is baie duidelik dat die gesag wat aan ampsdraers gegee is, hier 'n ander karakter toon as byvoorbeeld by Paulus en selfs in die deuteroPauliniese briewe. Die gesag wat aan Titus en Timoteus toegeken word, is 'n "uitvoerende" gesag waardeur die orde in die kerk en ook die suiwerheid van dit wat in die kerk verkondig word, bewaar moet word. Hierdie suiwerheid waarna Titus en Timoteus moet toesien, is van uiterste belang omdat dit met hierdie selfde suiwerheid is waarmee dwaalleer bestry moet word. Die bestryding van dwaalleer in die Pastorale Briewe word nou eerstens die verantwoordelikheid van die ampsdraers. Die feit dat daar baie sterk klem gelê word op die feit dat hulle aan die waarheid moet vashou en dit ook leer, dui daarop dat hulle nie die enigste was wat moes vasstaan in hierdie bestryding van die dwaalleer nie, maar dat die gelowiges wat deel van die gemeente is, hulle daarin moet bystaan. Die ouderlinge het egter die leiding geneem en die voorbeeld gestel.

Die groot verskil tussen Paulus en die Pastorale Briewe lê egter daarin dat die kerklike struktuur in die Pastorale Briewe meer gevestig was as by 


\section{'n Kerugmatiese perspektief op bedieninge in die Nuwe Testament}

Paulus. Paulus het self opsig gehou oor die verskillende gemeentes aan wie hy skryf. In die Pastorale Briewe is dit duidelik dat daar in sommige gevalle meer as een gemeente in een stad bestaan het. Van daar die monepiskopos wat sy dienswerk verrig kat a; p ovin.

Die feit dat dit reeds ' $n$ instelling geword het dat mense in sekere ampte georden word, en ook dat dit plaasvind by wyse van handoplegging, bevestig dat daar in die Pastorale Briewe reeds 'n groot ontwikkeling is wat getuig van 'n geïnstitusionaliseerde karakter. Hierdie ampspligte het ook uitgekring. Campbell (1994:204-205) stel dat die ontwikkeling van leierskap in die kerk van die Nuwe Testament in drie stadiums uiteengesit kan word. Hierdie drie stadiums is kat Foikon, kat FekkI hs ian en kat a;povin. Die eerste stadium van die kerk (kat Foikon) kan gesien word in die lig van opsig wat nog steeds deur die apostels gehou is. Die aantal gelowiges en die aantal huishoudings was nog baie min in hierdie beginstadium van die kerk. Tydens die tweede stadium (kat Fekk I hs i an) het die huishoudings meer begin word, en moes verskillende huishoudelike leiers ook saamwerk. Die derde stadium van kerklike ontwikkeling (kat a; p ovin) is duidelik in die Pastorale Briewe. Tydens hierdie stadium moet die kerke klaarkom sonder die opsig van die apostels, omdat die apostels in die tronk was of teen hierdie tyd dalk al dood.

\section{DIE AMP IN DIE VROEË KERK}

Dit sal die moeite loon om die skopus ook bietjie wyer te stel, en die kerk van die tweede en derde eeu ook in die gesigsveld bring.

In die tweede eeu het die "oudstes" wat die bedieninge in die kerk waargeneem het en die leiding in die groep van die oudste geneem het, begin om te ontwikkel in 'n amp. Hierdie amp het bekend gestaan as biskop. Die biskop het bepaalde magte gehad wat hy kon uitoefen, maar dit het nooit los van die ander biskoppe geskied nie. Die rol wat hierdie biskop in die gemeente vervul het, was niks anders as 'n pastor vir die gemeente nie.

In die tweede eeu het die biskop nog nie oor 'n gebied opsig gehou nie (Oetting 1964:43). Wat die verkiesing van die biskop in die tweede eeu betref, het ons weer te doen met die feit dat daar nie 'n uitsluitende hiërargie in die kerk bestaan het nie. Die verkiesing het plaasgevind by wyse van 'n verkiesing deur die plaaslike oudstes. In hierdie verkiesing kon die leke ook hulle stem laat hoor. Die verkiesing van 'n biskop was dus iets wat deur die gemeente gedoen is en nie net deur ander biskoppe nie. Ook ander biskoppe in die omgewing was betrokke by hierdie verkiesing.

'n Latere ontwikkeling in die kerk oor die verstaan van die biskopamp, het heeltemal 'n ander rigting ingeslaan. Ondersteuners van hierdie nuwe 
rigting was onder andere Ignatius en Siprianus. Siprianus het die gewigtige uitspraak gemaak dat die biskop 'n goddelike aanstelling is en dat hy die tussenganger is tussen God en die mens. Mense, sê hy, kan slegs in die kerk toegelaat word deur die goedkeuring van die biskop. Dié wat georden is, kan hulle ampswerk slegs begin wanneer hulle van die biskop toestemming ontvang het om dit te mag doen. Dit gebeur omdat God hierdie gesag aan die biskop gegee het. Die biskop is ook die enigste wat iemand mag ekskommunikeer.

\section{BEDIENINGE IN DIE NUWE TESTAMENT: 'N ONTWIKKELING VANAF JESUS TOT IN DIE KERK}

Dit is baie duidelik dat daar wat die bedieninge in die Nuwe Testament betref, 'n groot diversiteit bestaan. Dit is daarom onmoontlik om ' $n$ "vaste" begrip van bedieninge of ' $n$ bedieningspatroon uit die Nuwe Testament af te lei. Wat van belang is, is dat die verskillende verduidelikings van bedieninge in die Nuwe Testament soos wat dit gevind word in die afsonderlike dokumente van die Nuwe Testament, egter nie geïsoleer van mekaar verstaan moet word nie. Vanaf die beweging rondom Jesus, tot by die Pastorale Briewe, is daar 'n lyn van ontwikkeling te bespeur. Hierdie ontwikkeling het juis plaasgevind omdat daar ' $n$ diversiteit aanwesig is.

Die beste plek om te begin soek na 'n antwoord op die vraag na wat die bedoeling van die bedieninge in die Nuwe Testament is, is in Jesus se oproep tot dissipelskap in Matteus 16:24-28 en Markus 8:34-38. In die woorde van Jesus hoor ons wat God van ons wil hê, en daarom kan ook gesê word God se bedoeling met bedieninge in die kerk. Hierdie woorde van Jesus bring 'n mens die naaste aan dit wat God van jou vra. Hoewel Matteus en Markus se interpretasie van hierdie Jesus-woorde na-Pase is, is daar tog ook elemente van outentisiteit in hierdie woorde (kyk ook Van Aarde 2001:10-11). Omdat die kerk geen ander weg kan volg as juis om vir Jesus te volg nie, is dit belangrik dat Jesus se oproep tot dissipelskap ter harte geneem word.

lets wat ook kan help om 'n antwoord te kry, vind ons by Paulus in dit wat ons kan noem vier kerugmatiese waarhede, met ander woorde hoe Paulus gedink het oor kerk, charisma, bediening en kerugma. Wanneer Paulus oor die kerk praat dan gebruik hy die term ekkl hs i a, en bedoel hy daarmee ' $n$ versameling gelowiges wat bestaan uit Israeliete en hulle wat uit die heidendom bekeer is. Hy maak sy "in Christus"-formule van toepassing op hierdie versameling gelowiges. Christus self, maar ook die heil wat Hy bewerk het, is dus vir Paulus die samebindende faktor wat die gelowiges onderling saambind tot 'n eenheid, wat as die kerk bekendstaan. 
Paulus beklemtoon drie sake rakende charisma baie sterk. Eerstens die feit dat dit God is wat deur die Gees charisma aan mense gee, en daarom kom die roem en die eer daarvoor God alleen toe. Tweedens plaas die charismata 'n appèl op die mens om op 'n sekere manier te lewe. In die derde plek sê Paulus dat geen charisma verhewe is bo 'n ander nie. Charismata word alleen in die geloof ontvang. Wanneer hierdie charismata in die kerk neerslag vind in dienswerk wat gedoen word, moet die fokus steeds val op God wat daardeur aan die werk is, en nie daarop dat dit die mens is wat aan die werk is nie. Om hierdie rede noem Paulus gawes ook 'n manifestasie van die Gees.

By Paulus is die gedagte van die amp nog nie gevestig nie. Wat wel by Paulus bestaan, is sekere bedieninge. Paulus spreek nêrens in sy briewe mense aan wat in bepaalde ampte staan nie. Die gesag wat ter sprake is in die Pauliniese kerke, en waarmee die dienaars optree, is nie 'n amptelike gesag nie, maar 'n charismatiese gesag. Daarom kan gesê word dat God dus saam met die charisma ook die gesag gegee het waarmee die charisma beoefen moet word.

Die middelpunt van die kerklike verkondiging vir Paulus, is die verkondiging van die woord. Daar kan dus met stelligheid gesê word, dat die middelpunt van die kerugma by Paulus, watter gestalte dit ook al aanneem, is dat Jesus Christus die gekruisigde en opgestane Heer is. Verder regeer Hy self sy kerk regeer deur die charismata wat God aan mense gee. Hierdie mense, in gehoorsaamheid aan Christus, gebruik dit. Sonder Christus is daar volgens Paulus niks om te bely en niks om te kan glo nie.

\section{BEVINDING - DIE BEDIENINGE IN DIE NUWE TESTAMENT VANUIT 'N KERUGMATIESE PERSPEKTIEF}

Die vraag na wat die bedoeling agter die verskillende bedieninge in die Nuwe Testament is, kan na aanleiding van die opdrag van Jesus en die vier kerugmatiese waarhede by Paulus, beantwoord word aan die hand van die volgende stellings:

- $\quad$ Die eerste en belangrikste bedoeling van die bedieninge in die Nuwe Testament is dat die eer van God daardeur gedien moet word.

- $\quad$ Enige tipe bediening in die kerk is gegrond in bepaalde charismata wat God deur die Gees aan mense gee. Die verskillende bedieninge, of te wel die amp, lê in die verlengstuk van die charisma. 
- $\quad$ Op grond van die feit dat die charismata wat God gee, gelyk is in die sin dat die een gawe nie verhewe is bo die ander nie, beteken dus dat daar in die kerk ook geen uitsluitende hiërargie mag bestaan nie.

- $\quad$ Die bedoeling van die bedieninge in die Nuwe Testament is om daardeur ook die "wêreldvreemde" karakter van die kerk te beklemtoon. Dit vind ons baie pertinent in Jesus se oproep tot dissipelskap waar Hy stel dat dié een wat sy lewe wil behou dit sal verloor en dié wat ter wille van Hom hulle lewens verloor dit sal behou.

- $\quad$ Die bedieninge in die Nuwe Testament beklemtoon ook dat die kerk in navolging van die voorbeeld wat Jesus as Kurios van die kerk gestel het, diensbaar is in die wêreld. Hierdie diens word dan verder gekwalifiseer deur dit duidelik te maak dat dit diens is in die eerste plek aan God en in die tweede plek aan jou medemens.

- $\quad$ Na aanleiding van die liggaammetafoor, kan gesê word dat die bedieninge ook iets van die wedersydse afhanklikheid en verantwoordelikheid van al die lede van die liggaam konkretiseer.

- Laastens kan gesê word dat die charisma wat God aan die mens gee, 'n appèl op hom of haar plaas om in gehoorsaamheid aan God hierdie charisma te gaan uitleef. Ook word die appèl op die kerk geplaas om so te leef en te werk, en is die kerugma van die kerk gegrond in die charisma. Die bedoeling van die bedieninge in die Nuwe Testament is dus om daardeur ook die verkondiging van die kerk te dien.

Deur die bedieninge in die Nuwe Testament vanuit 'n kerugmatiese perspektief te sien, beteken dus om te verstaan dat God sondaars deur hulle dienswerk in die kerk wil gebruik. Hierdie mense moet in gehoorsaamheid aan God die orde in die kerk handhaaf, diensbaar wees aan die wêreld, en daardeur ook wys dat niemand bo 'n ander verhewe is nie, maar dat almal gelyk staan voor God. Dit alles kan egter nie geskied sonder bepaalde gawes wat God aan verskillende mense gee nie. Daarom is die belangrikste van alles wat die bedieninge in die Nuwe Testament ons leer, dat die eer van God as die Een wat alles gemaak het en steeds in stand hou, daardeur gedien word, en God se Naam groot gemaak word. 


\section{Literatuurverwysings}

Barth, K [1933] 1968. The epistle to the Romans, tr by E C Hoskyns. New York: Oxford University Press.

Brown, R E 1984. The churches the apostles left behind. New York: Paulist Press. Brox, N 1969. Die Pastoralbriefe. 4.Aufl. Regensburg: Pustet. (RNT 7/2.)

Bruders, H 1977. Existenz eine christlichen Amtes, in Kertelge 1977:83-92.

Bultmann, R 1955 [1983]. Theology of the New Testament, vol 1. $1^{\text {st }}$ British edition. London: SCM.

Campbell, R A 1994. The elders: Seniority within earliest Christianity. Edinburgh: T\&T Clark.

Dunn, J D G 1981. Unity and diversity in the New Testament: An inquiry into the character of earliest Christianity. London: SCM.

Dunn, J D G 1988. Romans 9-16. Dallas, TX: Word Books. (Word Biblical Commentary 38b.)

Hahn, F 1979. Charisma und Amt: Die Diskussion über das kirhliche Amt im Lichte der neuentestamentlichen Charismenlehre. ZThK 76, 419-449.

Hainz, J 1972. Ekklesia: Struktur paulinischer Gemeinde-Theologie und GemeindeOrdnung. Regensburg: Pustet. (BU9.)

Käsemann, E 1933. Leib und Leib Cristi: Eine Untersuchung zur paulinischen Begrifflichkeit. Tübingen: Mohr.

Kertelge, K (ed) 1977. Das kirchlice Amt im Neuen Testament. Darmstadt: Wissenschaftliche Buchgesellschaft.

Loader, W 2001. Jesus and the fundamentalism of his day. Grand Rapids, MI: Eerdmans.

Louw, J P \& Nida, E A 1989. Greek-English lexicon of the New Testament based on semantic domains, vol 1. Cape Town: Bible Society of South Africa.

Louw, J P \& Nida, E A 1989. Greek-English lexicon of the New Testament based on semantic domains, vol 2. Cape Town: Bible Society of South Africa.

Morris, L 1985. I Corinthians. Rev ed. Grand Rapids, MI: Eerdmans. (Tyndale New Testament Commentaries.)

Nederduitsch Hervormde Kerk van Afrika. Algemene Kerkvergadering 1970. Notule van die Algemene Kerkvergadering 1970. Argief Nederduitsch Hervormde Kerk, Pretoria.

Nederduitsch Hervormde Kerk van Afrika. Algemene Kerkvergadering 2001. Notule van die Algemene Kerkvergadering 2001. Argief Nederduitsch Hervormde Kerk, Pretoria.

Oetting, W 1964. The church of the catacombs: An introduction to the surging life of the early church from the apostles to $A D .25$ based on first hand accounts. St Louis, MO: Concordia Publishing House.

Osiek, C 2005. Diakonos and prostatis: Women's patronage in early Christianity. HTS 61, 347-370.

Pelser, G M M 1990. Die bedieninge in die Nuwe Testament: 'n Ondersoek na historiese wording en prinsipiële regverdigbaarheid. Praktiese Teologie in Suid Afrika 5, 1-18.

Pelser, G M M 1994. Enkele opmerkings oor die wese van die kerk. HTS 50, 311329.

Pelser, G M M 1995. Die kerk in die Nuwe Testament. HTS 51, 645-676. 
Pelser, G M M \& Van Aarde, A G 2004a. Inleiding tot en teologie van die outentieke Pauliniese briewe. Studiehandleiding, Departement Nuwe TestamentieseWetenskap, Universiteit van Pretoria.

Perlser, G M M \& Van Aarde, A G 2004b. Inleiding tot en teologie van die deuteroPauliniese briewe. Studiehandleiding, Departement Nuwe TestamentieseWetenskap, Universiteit van Pretoria.

Roloff, J 1978. sv Amt, Ämter, Amtverstädnis. TRE.

Schelke, H 1969. Dienste und Diener in den Kirchen der neuentestamentlichen Zeit, in Kertelge 1977:220-236.

Schnackenburg, R 1961. Die Kirche im Neuen Testament. Freiburg: Herder.

Schweitzer, E 1959. Gemeinde und Gemeindeordnung im Neuen Testament. Zurich: Zwingli Verlag. (AThANT 35.)

Schweitzer, E 1987. The nature of ministry in Reformed understanding: New Testament dimensions. Hor Bib Theol 9, 41-63.

Trilling, W 1978. Impliziete Ekklesiologie: Ein Vorschlag zum Thema "Jesu und die Kirche" in Trilling, W, Die Botschaft Jesu: Exegetische Orienterung, 57-72. Freiburg: Herder.

Van Aarde, A G 2001. Fatherless in Galilee: Jesus child of God. Harrisburg, PA: Trinity Press International.

Watson, D F 2003. Paul and boasting, in Sampley, J P (ed), Paul in the GrecoRoman world: A handbook, 77-100. Harrisburg, PA: Trinity Press International. (A Continuum imprint.) 